\title{
KAJIAN PERANCANGAN TERAS SEBAGAI RUANG TAMU NEW NORMAL DI RUMAH TINGGAL
}

\author{
Study of Terrace Design For Housing New Normal Guest Area
}

\section{R. Mohamad Wisnu Ibadi ${ }^{1}$ \\ ${ }^{1}$ Arsitektur, Universitas Tanri Abeng \\ Email:mohamad.wisnu@tau.ac.id}

\begin{abstract}
Abstrak
Penyakit yang disebabkan oleh virus Corona (Covid-19) menimbulkan pendemi wabah di seluruh dunia. Pandemi ini juga berlangsung di Indonesia sejak saat terdeteksi diawal Maret tahun 2020. Kondisi Pandemi ini menimbulkan banyak efek langsung maupun tidak langsung terhadap kegiatan manusia sehari-hari, termasuk dalam hal kegiatan sosial saat berhubungan dan berkomunikasi satu dengan lainnya. Dalam mengatasi pandemi, Pemerintah Indonesia mengeluarkan beberapa protokol kesehatan yang mengatur bagaimana warga negara berhubungan dan melakukan kegiatan sosial, yaitu menjaga jarak. memakai masker dan mencuci tangan (3M). Hal ini secara langsung maupun tidak langsung, menyebabkan perubahan manusia dalam melakukan komunikasi dan kegiatan sosialnya. Dalam penelitian ini, difokuskan kepada kegiatan manusia saat berkunjung atau bertamu ke rumah orang lain. Dimana kegiatan bertamu itu sangat lekat dengan pola kehidupan manusia Indonesia terkenal ramah dan senang melakukan hubungan silaturahmi ke teman, saudara atau tetangga yang biasa dilakukan di ruang tamu. Namun kondisi pandemic Covid menyebabkan suatu perubahan pola dan gaya hidup yang baru atau disebut New Normal. Penelitian ini bertujuan untuk melakukan sebuah kajian perancangan untuk menjadikan Teras Rumah sebagai Ruang Tamu New Normal.
\end{abstract}

Kata kunci: pandemi, bertamu, ruang tamu, teras

\section{PENDAHULUAN}

Pada hari Senin, Tanggal 2 Maret 2020, Presiden Joko Widodo, mengumumkan, Indonesia mauk ke dalam negara yang yang terjangkit pandemi Covid. Kemudian Kementrian Kesehatan mengeluarkan beberapa protokol kesehatan yang harus dijalankan oleh setiap warga negara Indonesia untuk mengontrol agar penularan virus Covid-19 tidak semakin meluas. Salah satu protokol kesehatan itu adalah 3M, yaitu menjaga jarak, memakai masker dan mencuci tangan. Selain itu pemerintah kemudian juga membatasi kegiatan semua warga negara dalam melakukan aktifitasnya dalam bentuk Pembatasan Sosial Berskala Besar (PSBB) di daerah-daerah yang terjangkit Covid19, seperti mewajibkan kegiatan belajar mengajar serta bekerja dilakukan dirumah, menutup sementara tempattempat ibadah, tempat-tempat rekreasi dan lain-lainnya.

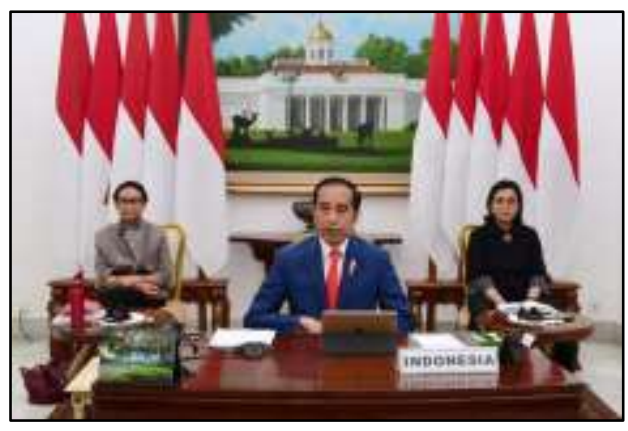

Gambar 1. Presiden Jokowi mengumumkan PSBB Sumber : katadata.co.id diakses 1 November 2021 
Secara langsung maupun tidak langsung kondisi pandemi COVID-19 kemudian membuat manusia selaku mahkluk sosial memakai cara baru dalam beraktifitas yang sering disebut dengan New Normal. Salah satunya adalah sekarang setiap orang saat keluar dari rumah wajib memakai masker untuk menjaga dirinya dari penularan bahaya Covid-19, tidak lagi menjabat tangan saat bertemu orang lain dan lain-lainnya.

Arsitektur adalah ilmu dan seni yang mempelajari rancangan bangunan atau ruang (space). Arsitektur secara etimologis berasal dari bahasa latin, architectura. Sedangkan dari bahasa Yunani adalah arkhitekon yang artinya tukang bangunan atau tukang kayu. Dalam melakukan perancangan bangunan, tentunya tidak lepas dari pengguna bangunan tersebut, yaitu manusia, dalam melakukan kegiatan dan aktifitasnya saat berada di dalam maupun diluar ruang atau bangunan.

Dari sekian banyak kegiatan dan aktifitas yang dilakukan oleh manusia, penelitian ini memfokuskan kepada ruang tamu di rumah tinggal yang digunakan oleh penghuni rumah saat menerima tamu. Tujuan penelitian ini adalah melakukan kajian untuk merancang ruang tamu New Normal di rumah tinggal.

\section{METODE}

Dalam penelitian ini, penulis memilih memakai metode penelitian kualitatif. Metode Penelitian Kualitatif yang dilakukan adalah komparatif deskriptif dengan datang, melakukan wawancara, melihat, memahami dan melakukan studi data literatur terkait penelitian rumah tinggal masa penjajahan Kolonial Belanda dan rumah-rumah adat dari suku Jawa, Sunda dan Betawi. Rumah tinggal adat suku Jawa, Sunda dan Betawi dipilih karena sama-sama berada di Pulau Jawa, yang sejak lama merupakan pusat kegiatan ekonomi di Indonesia serta pusat pemerintahan dari jaman penjajahan Kolonial Belanda hingga saat ini.

Fokus dalam penelitian ini adalah mengkaji pola perancangan ruang tamu di rumah-rumah tinggal arsitektur kolonial Belanda dan rumah adat suku Jawa, Sunda, Betawi. Tujuan penelitian adalah mempelajari pola perancangannya untuk menemukan pola perancangan ruang tamu yang tepat bagi kondisi New Normal.

\section{PEMBAHASAN}

\section{Ruang Tamu}

Ruang tamu adalah tempat dimana tuan rumah menerima tamu yang datang berkunjung ke rumahnya. Dalam hal ini pengguna ruang tamu berarti tuan rumah dan tamu. Dalam Kamus Besar Bahasa Indonesia (KBBI), tamu adalah orang yang datang berkunjung (melawat dan sebagainya) ke tempat orang lain atau ke perjamuan. Tamu yang datang berkunjung ke sebuah rumah tinggal, terdiri atas beberapa kategori sebgai berikut :

1. Tamu tidak dikenal. Masuk kategori ini adalah Tukang Pos atau pengantar barang, penjual keliling, pengemis, pemulung dan lainnya. Tamu jenis ini akan diterima oleh tuan rumah di area zoning publik, yaitu didepan jalan depan pagar rumahnya. Interaksi yang dilakukan dibatasi oleh pagar. Waktu interaksi singkat, sebab dilakukan dengan keadaan berdiri didepan pagar.

2. Tamu dikenal. Masuk ke dalam kategori ini adalah tetangga, teman atau orang yang cukup dikenal dengan baik oleh tuan rumah sehingga tidak segan dan merasa aman untuk membuka pintu pagar rumahnya lalu mempersilakan tamu tersebut masuk ke dalam rumah serta duduk di ruang tamu. Dalam perancangan organisasi ruang untuk rumah tinggal, ruang tamu termasuk ke 
dalam area zoning semi publik, yang mengijinkan orang luar selain penghuni rumah untuk bisa masuk ke area bangunan rumah tinggal. Waktu untuk interaksi cukup lama, sebab dilakukan dengan keadaan duduk. Dalam tata karma kesopanan, tuan rumah akan menyajikan minuman dan cemilan untuk tamu kategori ini.

3. Tamu dekat. Masuk ke dalam kategori ini adalah teman dekat, saudara, atau keluarga dari penghuni rumah. Tamu dalam kategori ini biasanya diijinkan untuk masuk dan mengobrol dengan tuan rumah di Ruang Keluarga, untuk menunjukkan kedekatan tuan rumah kepada tamu. Dalam organisasi ruang, Ruang Keluarga masuk ke dalam area zoning semi privat, sehingga tidak setiap orang dapat masuk ke ruangan ini yang biasa digunakan oleh anggota keluarga penghuni rumah untuk berkumpul dan menghabiskan waktu. Karena bertujuan untuk anggota keluarga berkumpul maka furnitur ruang keluarga biasanya adalah sofa demi kenyamanan. Waktu interaksi paling lama, karena tuan rumah akan berusaha membuat tamu merasa betah dan nyaman saat kunjungan.

Fokus dalam penelitian ini adalah Ruang Tamu yang berada di area zoning semi publik. Area ini biasanya berada di depan rumah tinggal. Kelengkapan furnitur untuk ruang tamu untuk rumah tinggal biasanya terdiri dari dua buah kursi untuk tuan rumah, serta dua kursi untuk tamu dan sebuah meja tamu.

\section{Rumah Tinggal Arsitektural Masa Kolonial Belanda}

Dalam masa penjajahannya, Pemerintah Kolonial Belanda, sering disebut dengan nama Pemerintahan Hindia Belanda. Hindia Belanda dalam Bahasa Indonesia atau Nederlandsch Indie, merupakan penamaan kerajaan Belanda kepada negeri jajahannya yang berada di Asia Timur, sehingga sering disebut juga Nederlandsch Oost Indie yang berarti Pemerintahan Belanda Timur Jauh. Yang pertama kali datang ke Indonesia adalah Vereenidge Oost Indische Compagnie (VOC) atau Kongsi Dagang Perusahaan Hindia Timur Belanda, pada tahun 1619.

Pada awalnya VOC datang dengan tujuan perdagangan, namun kemudian VOC menjajah kerajaan-kerajaan di seluruh Indonesia sebelum akhirnya dibubarkan tanggal 31 Desember 1799 dan diserahkan kepada Pemerintah Belanda. Selama tiga abad, Belanda menguasai Indonesia memiliki akibat di seluruh bidang kehidupan masyarakat Indonesia. Salah satunya adalah dalam bidang ilmu Arsitektur di Indonesia. Gaya Arsitektur Jaman Kolonial ini kemudian dikenal dengan nama Indis.

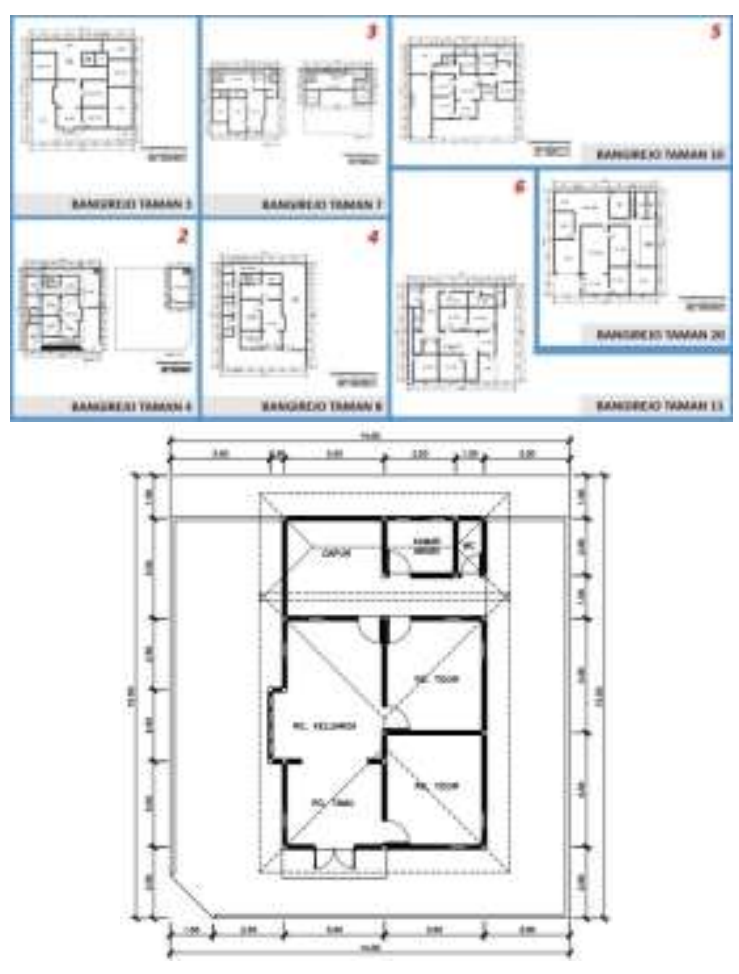

Gambar 2. Denah Rumah-rumah Tinggal Kolonial di Kawasan Bangirejo Taman, Yogyakarta (2020)

Sumber : Pindo Tutuko, Ciri Khas Arsitektur Rumah Belanda. 2003, diakses tanggal 1 November 2021 
Pemerintahan Hindia Belanda di masa itu membuat peraturan tentang bangunan gedung perkantoran dan rumah kedinasan Pemerintah Belanda memakai istilah Indische Huizen atau Indo Europeesche Bouwkunst (Pindo Tutuko, 2003). Gaya Arsitektur Indis sudah tidak lagi murni bergaya eropa, tetapi memiliki unsur yang memperhatikan kondisi iklim tropis karena geografis kepulauan Indonesia yang terletak di garis katulistiwa. Dari segi politis, pengertian arsitektur Indis juga dimaksud untuk membedakan dengan bangunan adat atau tradisional yang lebih dahulu ada, bahkan oleh Pemerintah Belanda bentuk bangunan Indis dikukuhkan sebagai gaya yang harus ditaati, sebagai simbol kekuasaan saat itu. Penelitian yang dilakukan oleh Dimas Wihardyanto dan Ikaputra terhadap bangunan rumah tinggal peninggalan kolonial Belanda di Bangirejo Taman Yogyakarta, memperlihatkan sebuah kemiripan pembagian organisasi ruang dan zonasi publik, privat servis arsitektur kolonial Hindia Belanda masa itu dengan saat ini, yaitu penempatan ruang tamu di area dalam rumah tinggal (sisi depan rumah), pengaturan kamar tidur, ruang keluarga, dapur, kamar mandi dan WC.

Hal ini memperlihatkan bahwa pola organisasi ruang pada masa kolonial Belanda telah berakar dalam di arsitektur modern Indonesia hingga saat ini. Meski gaya Arsitektur Indis dalam hal tampak dan bentuk sudah tidak lagi digunakan sejak kemerdekaan Indonesia dari penjajahan Belanda, pola organisasi ruang peninggalan kolonial Belanda masih bertahan hingga saat ini.

Namun pandemi Covid-19 membuat pola organisasi ruang dengan menempatkan posisi ruang tamu di dalam area rumah tinggal sudah tidak lagi sesuai bagi kondisi New Normal. Hal ini karena menyebabkan resiko yang tinggi terhadap kesehatan penghuni rumah saat Tamu berkunjung karena kondisi ruang tertutup dan sirkulasi angin yang terbatas.

\section{Rumah Adat Betawi}

Pemerintah Daerah Provinsi DKI Jakarta mengeluarkan Peraturan Daerah (Perda) nomor 4 tahun 2015, tentang pelestarian kebudayaan Betawi termasuk didalamnya berisi pelestarian arsitektur Betawi. Salah satu program Pemerintah Provinsi DKI Jakarta dalam melestarikan kebudayaan Betawi adalah dengan melakukan pengembangan sebuah area yang berciri budaya tradisional Betawi, berlokasi di Setu Babakan. Lokasi tersebut lalu diberi nama "Kampung Budaya Betawi".

Rumah tradisional Betawi terbagi menjadi dua yaitu tipologi berdasarkan lokasi dan bentuk. Berdasarkan tipologi bentuk, maka rumah adat Betawi terbagi menjadi tiga, yaitu Rumah Gudang, Rumah Joglo dan Rumah Kebaya.
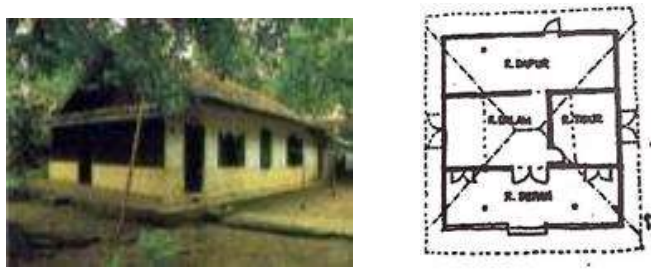

Gambar 3. Rumah Adat Betawi - Rumah Gudang
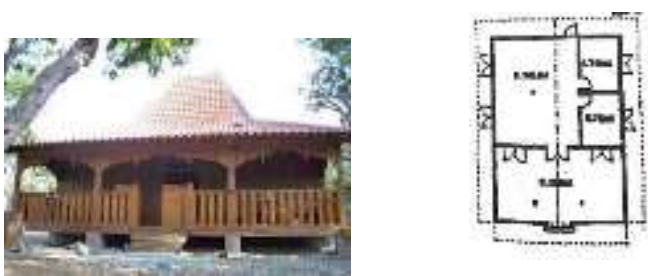

Gambar 4. Rumah Adat Betawi - Rumah Joglo
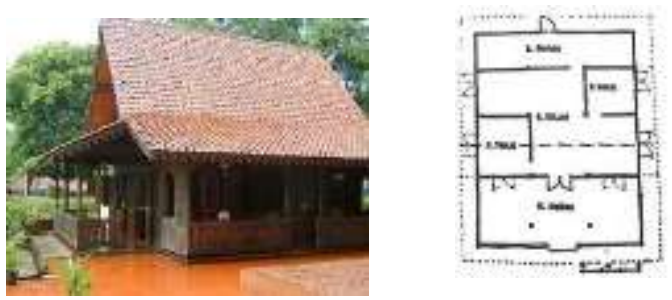

Gambar 5. Rumah Adat Betawi - Rumah Kebaya Sumber: Harun, I. (1991), diakses tanggal 2 November 2021 
Dari ketiga gambar diatas, maka dapat dilihat ada sebuah kesamaan pada Denah pengaturan ruangannya, yaitu peletakan Teras yang berada di area depan rumah.

Dari denah ketiga rumah adat betawi diatas, ada tiga area zoning, yaitu :

(a) Ruang depan (publik): paseban, teras berfungsi sebagai area berkumpul baik antar penghuni rumah maupun penghuni rumah terhadap tamu yang terletak pada bagian depan rumah.

(b)Ruang inti (privat): Ruang keluarga, Ruang makan, Kamar tidur yang terletak pada bagian tengah rumah.

(c) Pandasan (servis): Kamar mandi, Dapur terletak pada bagian belakang rumah.

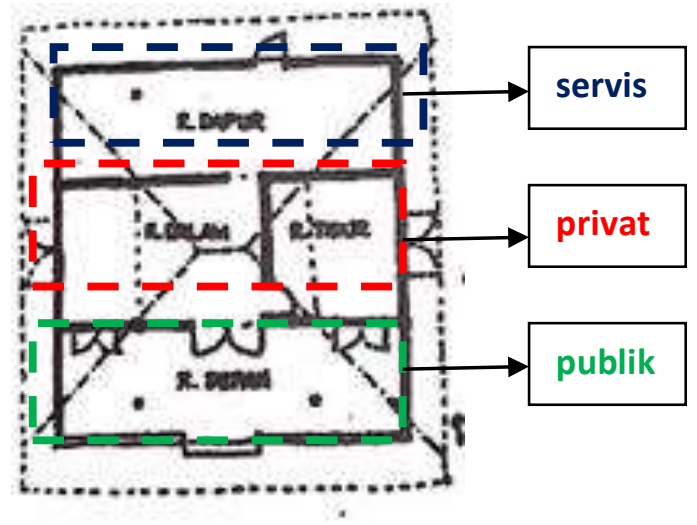

Gambar 6. Zonasi di Rumah Adat Betawi Sumber : Hayudian Pramesiwara. (2019) diakses tanggal 2 November 2021

Paseban atau Teras di rumah adat Betawi berbentuk ruang terbuka yang luas, berfungsi sebagai tempat tuan rumah menerima tamu sekaligus ruang keluarga bagi penghuni rumah. Kondisi ruang terbuka ini membuat sirkulasi pergerakan angin yang baik tapi tidak panas, karena terlindung dari panas sinar matahari langsung berkat naungan atap diatasnya.

\section{Rumah Adat Jawa}

Rumah tinggal adat Jawa, memiliki nilainilai filosofi seni budaya suku Jawa didalamnya. Arsitektur rumah adat Jawa juga memiliki nilai historis yang tinggi, terilihat dari rumah adat Jawa di masa lalu terlihat dari relief-relief Candi Borobudur.
Saat ini rumah adat Jawa berdasarkan tipologi bentuk atapnya terbagi menjadi empat, yaitu Atap Kampung, Atap Limasan, Atap Tajuk dan Atap Joglo.

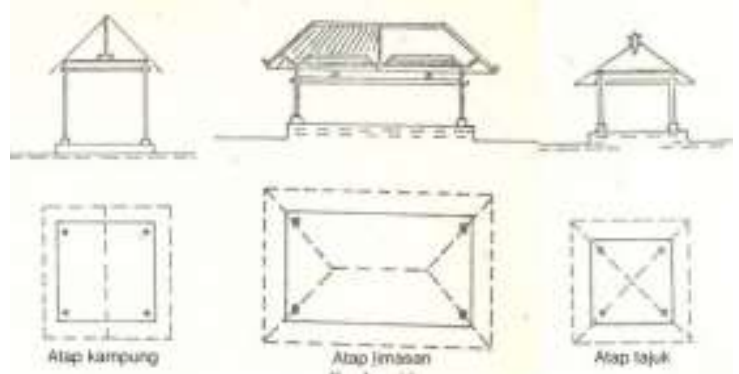

Gambar 7. Bentuk Atap Rumah Adat Jawa

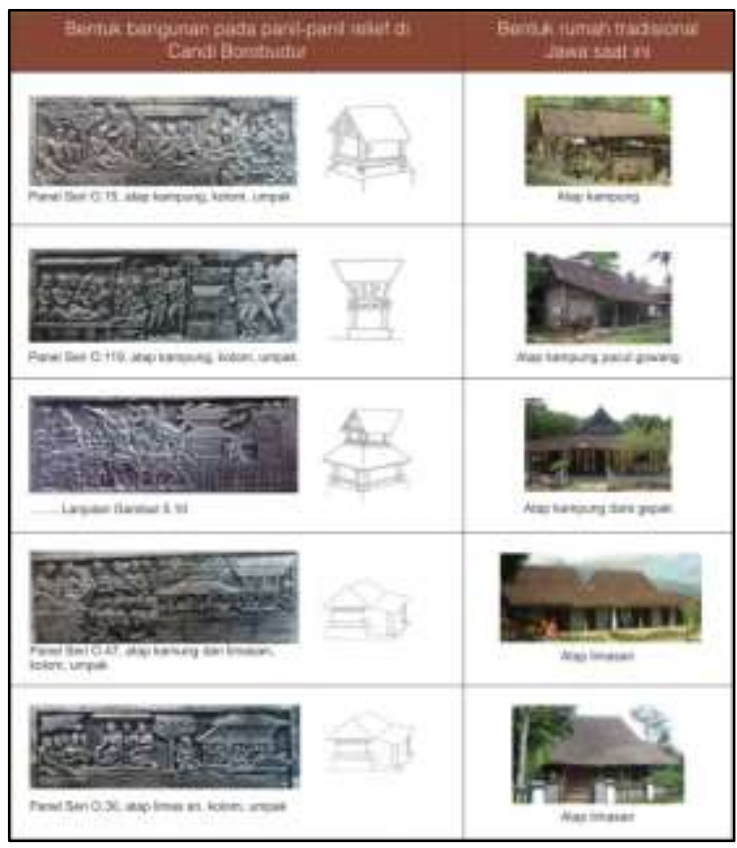

Gambar 8. Rumah Adat Jawa di Candi Borobudur Sumber : arsitekturdanlingkungan.wg.ugm.ac.id diakses tanggal 3 November 2021
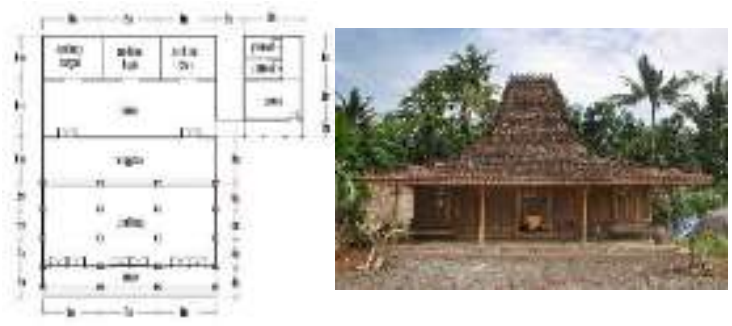

Gambar 9. Rumah Adat Jawa - Atap Joglo Sumber : katadata.co.id dikases tanggal 3 November 2021

Rumah adat Jawa yang memiliki nilai filosofi dan susunan paling lengkap dan penuh akan nilai-nilai kearifan seni budaya suku Jawa adalah Rumah Joglo. Rumah Joglo biasanya hanya dimiliki oleh kaum 
bangsawan, keluarga raja atau orang kaya dan terpandang. Rumah Joglo memiliki ukuran lahan yang paling luas dari lainnya. Berikut susunan Pola Ruang Rumah Joglo :

1. Lawang Pintu, adalah tempat keluar masuk ke komplek rumah (gerbang).

2. Pendopo, adalah sebuah pavilion yang terletak di sisi depan komplek. Tempat ini dipakai untuk menerima tamu, pertemuan sosial,

3. Peringgitan, adalah ruang diantara Pendopo dan bangunan utama

4. Emperan

5. Dalem, adalah berlangsungnya semua kegiatan penghuni rumah. Sekaligus tempat tidur anggota keluarga.

6. Senthong, adalah ruang penyimpanan padi dan hasil pertanian lainnya. Juga sebagai ruang khusus bagi Dewi Sri.

7. Gandok, adalah bangunan tambahan untuk anggota keluarga

8. dapur

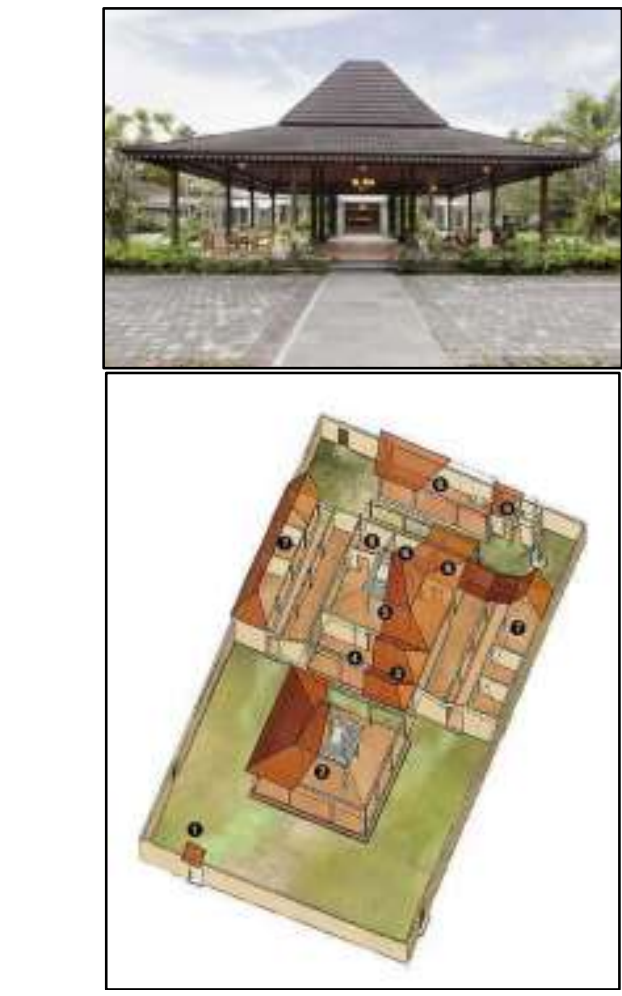

Gambar 10. Rumah Adat Jawa Joglo - Pendopo Sumber : katadata.co.id diakses tanggal 3 November 2021
Ciri khas utama dari Rumah Joglo adalah empat tiang utama ditengah bangunan utama yang dinamakan Soko Guru. Dari pola organisasi ruang Rumah Joglo di rumah adat Jawa, ada 2 jenis pendopo, yaitu menyatu dengan bangunan dan terpisah dari bangunan utama. Rumah Joglo dengan Pendodo yang terpisah oleh bangunan utama, umumnya dimiliki oleh keluarga raja dan kaum bangsawan, karena membutuhkan ruang terbuka yang luas saat mengadakan pertemuan dengan para bawahannya. Sementara Pendopo yang menyatu dengan bangunan utama memiliki luas yang lebih kecil dan lebih terbatas daya tampungnya.

Karena berbentuk terbuka tanpa dinding, Pendopo Rumah adat Joglo yang terpisah dari Omah bangunan utama memiliki sirkulasi udara yang baik dan terlindung panas matahari berkat bentuk atapnya.

\section{Rumah Adat Sunda}

Provinsi Jawa Barat, memiliki seni dan budaya yang beragam karena memiliki beberapa suku didalamnya, seperti Baduy, Cirebon, Sunda, dan Betawi. Suku Sunda memiliki sejarah sangat panjang dari jaman kerajaan tertua di Indonesia Salakanegara dan Tarumanagara.

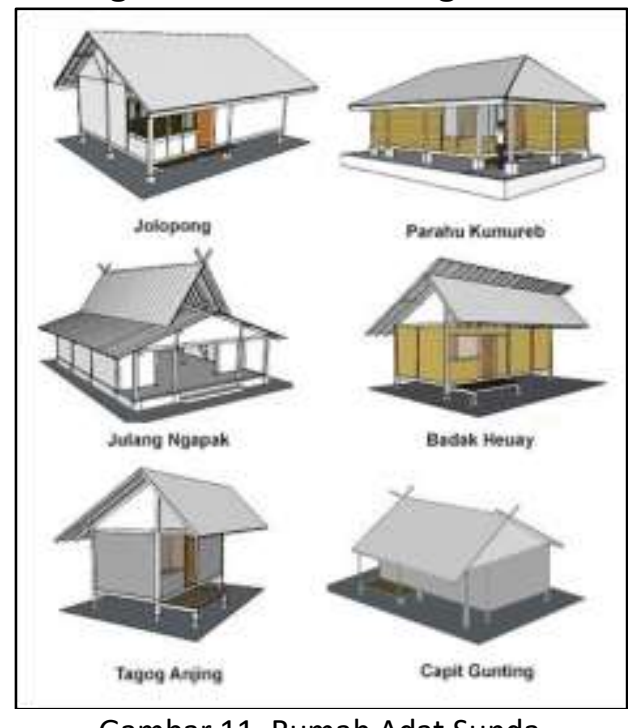

Gambar 11. Rumah Adat Sunda

Sumber : Departemen Pendidikan dan Kebudayaan Jawa Barat diakses tanggal 4 November 2021 
Berdasarkan Bentuk Tipologi Bangunan, rumah adat Sunda terbagi atas: Suhunan Jolopong, Tagog Anjing, Badak Heuai, Parahu Kumureb, Julang Ngapak, dan Capit Gunting.

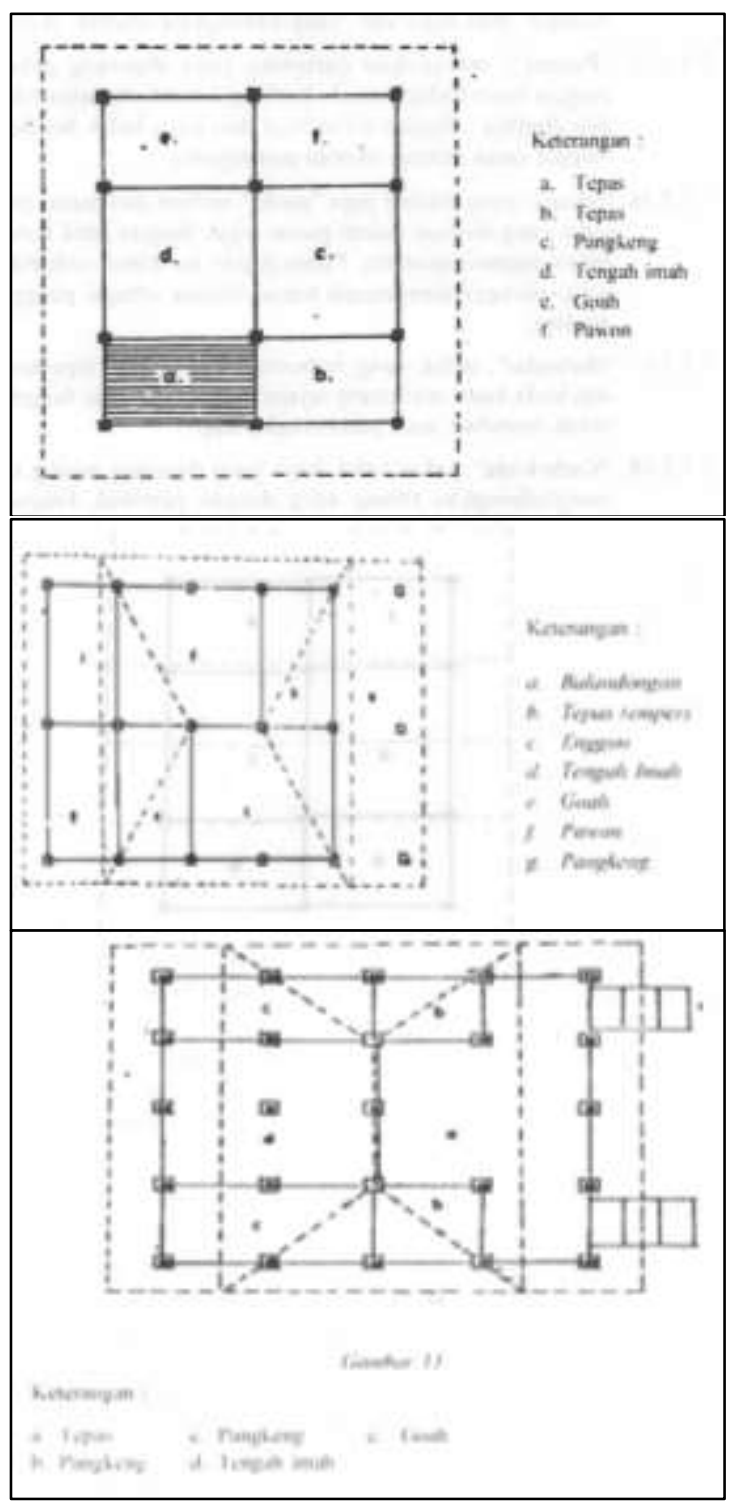

Gambar 12. Pola Ruang Rumah Adat Sunda Sumber : Departemen Pendidikan dan Kebudayaan Jawa Barat diakses tanggal 4 November 2021

Dalam pola ruang rumah adat Sunda, Tepas atau emper terleta di depan. Fungsi Tepas adalah untuk menerima tamu. Tamu akan diterima duduk langsung dilantai atau diberi alas tikar pandan. Hal ini sesuai dengan kebiasaan masyarakat Sunda yang senang akan lesehan atau duduk langsung bersila di lantai tanpa alas duduk. Namun kini biasa dijumpai meja, kuris dan bale-bale untuk duduk.

Tepas atau emper yang terletak di depan rumah, memiliki sirkulasi udara yang baik karena tidak tertutup oleh dinding.

\section{Panduan Green Building Council Indonesia}

Dalam webinar yang diselenggarakan oleh Green Building Council Indonesia (GBCl), bertema Keeping Our Indoor Quality, Safe and Healthy During Pandemic Era pada tanggal 27 Juli 2021 ditekankan sirkulasi udara didalam ruangan harus pantau dan ditukar dengan udara luar. Sehingga terjadi penggantian udara dalam dengan udara luar dengan mengurangi pemakaian penghawaan buatan (air conditioning), dibukanya jendela dan kipas yang mengarah ke jendela terbuka.

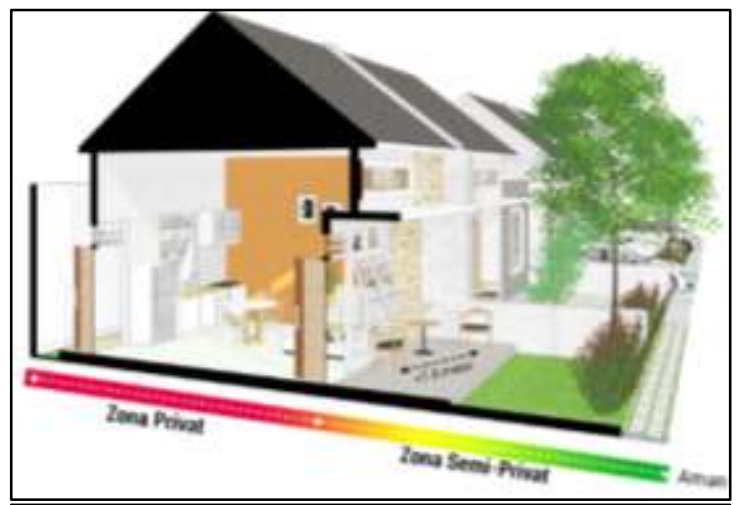

Batasi kunjungan non-anggota keluarga ke dalam rumah. Jika hal itu terpaksa terjadi maka kedua belah pihak harus menggunakan masker double dan jendela harus dibuka, dan mempersingkat durasi pertemuan.

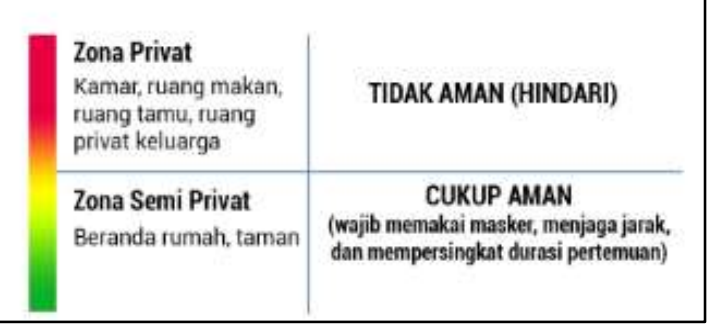

Gambar 13. Panduan GBCl

Sumber : Seminar GBCl tanggal 27 Juli 2021

Dalam panduannya, $\mathrm{GBCl}$ juga membatasi tamu yang berkunjung di rumah atau menerima tamu di luar rumah atau teras 
yang memiliki sirkulasi udara terbuka. Hal ini bertujuan agar sirkulasi udara mengurangi resiko penularan COVID 19.

\section{HASIL DAN KESIMPULAN}

Dari penelitian diatas dapat disimpulkan beberapa hal, antara lain pola organisasi ruang rumah tinggal di Indonesia memiliki kemiripan susunan ruang dengan pola organisasi ruang rumah-rumah tinggal peninggalan jaman Kolonial Belanda. Salah satunya adalah penerapan Ruang Tamu yang masuk ke dalam bangunan. Hal ini berbeda dari penerapan pola ruang tamu di rumah-rumah adat Jawa, Betawi dan Sunda, yang menempatkan ruang tamu di area luar dan sirkulasi udara luar.

Dalam kondisi New Normal di era Pandemi Covid 19, pola organisasi ruang tamu seperti saat ini sudah tidak bisa lagi digunakan, karena sirkulasi udara yang dibatasi oleh dinding dalam ruangan meningkatkan tingginya resiko penularan Covid-19 dari tamu ke tuan rumah dan sebaliknya. Oleh sebab itu $\mathrm{GBCl}$ memberi saran untuk membatasi kunjungan tamu atau menerima tamu di luar ruang seperti pagar dan teras, tapi tetap bermasker.

Sebagai mahluk sosial, manusia tidak mungkin lepas dari hubungan silaturahmi atau saling berkunjung ke rumah orang lain untuk bertatap muka secara langsung, sehingga ruang tamu tetap dibutuhkan di pola organisasi ruang rumah tinggal meski di kondisi New Normal Pandemi Covid.

Melihat hal tersebut, maka perancangan ruang tamu untuk rumah tinggal di kondisi New Normal bisa kembali kepada nilainilai luhur budaya (Genius Loci) masyarakat suku Jawa, Betawi dan Sunda yang menempatkan ruang tamu di luar ruang dengan sirkulasi udara terbuka.
Perancangan teras untuk rumah tinggal selama ini diabaikan di pola organisasi ruang dengan kecilnya luas area yang diberikan sudah saatnya untuk dirubah. Program Ruang untuk Perancangan Teras bagi rumah tinggal sebaiknya diperbesar sehingga bisa sekaligus menjadi ruang tamu kondisi New Normal, dengan konsep terbuka di luar area rumah, tidak berdinding sehingga bertujuan memiliki sirkulasi udara terbuka.

\section{DAFTAR PUSTAKA}

Pindo Tutuko (2003), Ciri Khas Arsitektur Rumah Belanda...https://jurnal.unmer.ac.id/index.php/ja m/article/view/1954/1273

Hayudian Pramesiwara (2019, September 39-44) Pola Ruang Dalam Pada Rumah Tradisional Betawi (Prosiding Seminar) Intelektual Muda \#2, Peningkatan Kualitas Hidup dan Peradaban Dalam Konteks IPTEKSEN https://trijurnal.lemlit.trisakti.ac.id/sim/article/do wnload/6585/4978

Nani Sriwadani (2018), Tinjauan Bentuk Sirkulasi Udara Rumah Adat Kampung Cikondang, Desa Lamajang, Kabupaten Bandung. NARADA, Jurnal Desain \& Seni, FDSK - UMB

https://publikasi.mercubuana.ac.id/index.php/nar ada/article/viewFile/4060/2062

Orbita, Gerarda. (2012). Tata Ruang dan Elemen Arsitektur pada Rumah Jawa di Yogyakarta sebagai Wujud Kategori Pola Aktivitas di Dalam Rumah Tangga. Jurnal Arsitektur Komposisi. Vol.10 No. 2

https://ojs.uajy.ac.id/index.php/komposisi/article/ view/1064/899

Departemen Pendidikan dan Kebudayaan Jawa Barat. (1984). Arsitektur Tradisional Daerah Jawa Barat, Bandung: Departemen Pendidikan dan Kebudayaan Jawa Barat http://repositori.kemdikbud.go.id/8239/1/ARSITEK TUR\%20TRADISIONAL\%20DAERAH\%20JAWA\%20B ARAT.pdf

dr. RizaL Fadli (2021. 11 Juni). Begini Kronologi Lengkap Virus Corona Masuk Indonesia. halodoc.com.https://www.halodoc.com/artikel/kr onologi-lengkap-virus-corona-masuk-indonesia 
Dimas Jarot Bayu (2020, 31 Maret). Jokowi Putuskan PSBB Dan Status Darurat Atasi Corona. katadata.co.id.

https://katadata.co.id/yuliawati/berita/5e9a41f7b 0e12/jokowi-putuskan-psbb-dan-status-daruratkesehatan-atasi-corona

Jevi Nugraha (2020, 31 Desember) 31 Desember : Berakhirnya Kekuasaan VOC di Indonesia. merdeka.com.

https://www.merdeka.com/jateng/peristiwa-31desember-berakhirnya-kekuasaan-voc-diindonesia-kln.html

Arsitektur Lingkungan (2015, 21 November). Bangunan Rumah Pada Relief Candi Borobudur. ugm.ac.id.

https://arsitekturdanlingkungan.wg.ugm.ac.id/201 5/11/21/bangunan-rumah-pada-relief-candiborobudur

Niken Aninsi (2021, 29 September). Mengenal Jenis Rumah Joglo, Bangunan Adat Suku Jawa Penuh Filosofi. katadata.co.id. https://katadata.co.id/intan/berita/615425c636ea 7/mengenal-jenis-rumah-joglo-bangunan-adatsuku-jawa-penuh-filosofi 